\title{
Animal Liberation and Environmental Ethics: Bad Marriage, Quick Divorce
}

Mark Sagoff

Follow this and additional works at: http://digitalcommons.osgoode.yorku.ca/ohlj Article

\section{Citation Information}

Sagoff, Mark. "Animal Liberation and Environmental Ethics: Bad Marriage, Quick Divorce." Osgoode Hall Law Journal 22.2 (1984) : 297-307.

http://digitalcommons.osgoode.yorku.ca/ohlj/vol22/iss2/5

This Article is brought to you for free and open access by the Journals at Osgoode Digital Commons. It has been accepted for inclusion in Osgoode Hall Law Journal by an authorized editor of Osgoode Digital Commons. 


\title{
ANIMAL LIBERATION AND ENVIRONMENTAL ETHICS: BAD MARRIAGE, QUICK DIVORCE
}

\author{
By MARK SAGOFF*
}

I.

"The land ethic," Aldo Leopold wrote in A Sand County Almanac, "simply enlarges the boundaries of the community to include soils, waters, plants, and animals, or collectively, the land." What kind of community does Leopold refer to? He might mean a moral community, for example, a group of individuals who respect each other's right to treatment as equals or who regard one another's interests with equal respect and concern. He may also mean an ecological community, that is, a community tied together by biological relationships in interdependent webs or systems of life. ${ }^{2}$

Let us suppose, for a moment, that Leopold has a moral community in mind; he would expand our moral boundaries to include not only human beings, but also soils, waters, plants and animals. Leopold's view, then, might not differ in principle from that of Christopher Stone, who has suggested that animals and even trees be given legal standing, so that their interests may be represented in court. ${ }^{3}$ Stone sees the expansion of our moral consciousness in this way as part of a historical progress by which societies have recognized the equality of groups of oppressed people, notably blacks, women and children. ${ }^{4}$ Laurence Tribe eloquently makes the same point:

What is crucial to recognize is that the human capacity for empathy and identification is not static; the very process of recognizing rights in those higher vertebrates with whom we can already empathize could well pave the way for still further extensions as we move upward along the spiral of moral evolution. It is not only the human liberation movements - involving first blacks, then

- Copyright, 1984, Mark Sagoff.

* Research Associate for the Center for Philosophy and Public Policy, University of Maryland.

1 Leopold, A Sand County Almanac (1949) at 204.

2 For discussion, see Heffernan, The Land Ethic: A Critical Appraisal (1982), 4 Envt'l Ethics 235. Heffernan notes that "when Leopold talks of preserving the "integrity, stability and beauty of the biotic community' he is referring to preserving the characteristic structure of an ecosystem and its capacity to withstand change or stress." Id. at 237.

s Stone, Should Trees Have Standing? (1974).

Id. at 44. 
women, and now children - that advance in waves of increased consciousness. ${ }^{\circ}$

Peter Singer, perhaps more than any other writer, has emphasized the analogy between human liberation movements (for example, abolitionism and sufferagism) and "animal liberation" or the "expansion of our moral horizons" to include members of other species in the "basic principle of equality." in two respects. First, he argues that the capacity of animals to suffer pain or to enjoy pleasure or happiness places people under a moral obligation which does not need to be enhanced by a doctrine about rights. Second, while Stone is willing to speak of the interests of his lawn in being watered, ${ }^{7}$ Singer argues that "only a being with subjective experiences, such as the experience of pleasure or the experience of pain, can have interests in the full sense of the term." A tree, as Singer explains, may be said to have an "interest" in being watered, but all this means is that it needs water to grow properly as an automobile needs oil to function properly. ${ }^{9}$ Thus, Singer would not include rocks, trees, lakes, rivers or mountains in the moral community or the community of morally equal beings.

Singer's thesis, then, is not necessarily that animals have rights which we are to respect. Instead, he argues that they have utilities that ought to be treated on an equal basis with those of human beings. Whether Tribe and Stone argue a weaker or a different thesis depends upon the rights they believe animals and other natural things to have. They may believe that all animals have a right to be treated as equals, in effect, they may agree with Singer that the interests of all animals should receive equal respect and concern. On the other hand, Tribe, Stone or both may believe that animals have a right only to life or only to those very minimal and basic rights without which they could not conceivably enjoy any other right. ${ }^{10} \mathrm{I}$ will, for the moment, assume that Tribe and Stone agree that animals have basic rights, for example, a right to live or a right not to be killed for their meat. I will consider later the possibility that environmental law might protect the rights of animals without necessarily improving their welfare or protecting their lives.

- Tribe, Ways Not to Think About Plastic Trees: New Foundations in Environmental Law (1973), 83 Yale L. J. 1315 at 1345.

- Singer, All Animals Are Equal (1974), 1 Phil. Exchange 103.

7 Stone, supra note 3, at 24.

singer, "Not For Humans Only: The Place of Nonhumans in Environmental Issues," in Goodpaster and Sayre, eds., Ethics And The Problems of the Twenty-first Century (1979) at 194.

- Id. at 195.

10 For a discussion of basic rights, see Shue, Basic Rights (1980). 
Moral obligations to animals, to their well-being or to their rights, may arise in either of two ways. First, duties to non-human animals may be based on the principle that cruelty to animals is obnoxious, a principle nobody denies. Muckraking journalists (thank God for them) who depict the horrors which all too often occur in laboratories and on farms, appeal quite properly to the conviction and intuition that people should never inflict needless pain on animals and especially not for the sake of profit. When television documentaries or newspaper articles report the horrid ways in which domestic animals are often treated, the response is, as it should be, moral revulsion. This anger is directed at human responsibility for the callous, wanton and needless cruelty human beings inflict on domestic animals. It is not simply the pain but the way it is caused which justifies moral outrage.

Moral obligations, however, might rest instead on a stronger contention, which is that human beings are obliged to prevent and to relieve animal suffering however it is caused. Now, insofar as the animal equality or animal liberation movement makes a philosophically interesting claim, it insists on the stronger thesis, that there is an obligation to serve the interests, or at least to protect the lives, of all animals who suffer or are killed, whether on the farm or in the wild. Singer, for example, does not stop with the stultifying platitude that human beings ought not to be cruel to animals. No; he argues the controversial thesis that society has an obligation to prevent the killing of animals and even to relieve their suffering wherever, however, and as much as it is able, at a reasonable cost to itself.

II.

I began by supposing that Aldo Leopold viewed the community of nature as a moral community-one in which human beings, as members, have obligations to all other animals, presumably to minimize their pain. I suggested that Leopold, like Singer, may be committed to the idea that the natural environment should be preserved and protected only insofar as, and because, its protection satisfies the needs or promotes the welfare of individual animals and perhaps other living things. I believe, however, that this is plainly not Leopold's view. The principle of natural selection is not obviously a humanitarian principle; the predator-prey relation does not depend on moral empathy. Nature ruthlessly limits animal populations by doing violence to virtually every individual before it reaches maturity; these conditions respect animal equality only in the darkest sense. Yet these are precisely the ecological relationships which Leopold admires; they are the conditions which he would not interfere with, but protect. Apparently, Leopold does not 
think that an ecological system has to be an egalitarian moral system in order to deserve love and admiration. An ecological system has a beauty and an authenticity that demands respect - but plainly not on humanitarian grounds.

In a persuasive essay, J. Baird Callicott describes a number of differences between the ideas of Leopold and those of Singer - differences which suggest that Leopold's environmental ethic and Singer's humane utilitarianism lead in opposite directions. First, while Singer and other animal liberationists deplore the suffering of domestic animals, "Leopold manifests an attitude that can only be described as indifference."11 Second, while Leopold expresses an urgent concern about the disappearance of species, Singer, consistently with his premises, is concerned with the welfare of individual animals, without special regard to their status as endangered species. Third, the preservation of wilderness, according to Leopold, provides "a means of perpetuating, in sport form, the more virile and primitive skills. . . " 12 He had hunting in mind. Leopold recognized that since top predators are gone, hunters may serve an important ecological function. Leopold was himself an enthusiastic hunter and wrote unabashedly about his exploits pursuing game. The term "game" as applied to animals, Callicott wryly comments, "appears to be morally equivalent to referring to a sexually appealing young woman as a "piece" or to a strong, young black man as a "buck" - if animal rights, that is, are to be considered on par with women's rights and the rights of formerly enslaved races."13

Singer expresses disdain and chagrin at what he calls "environmentalist" " organizations such as the Sierra Club and the Wildlife Fund, which actively support or refuse to oppose hunting. I can appreciate Singer's aversion to hunting, but why does he place the word "environmentalist" in shudder quotes when he refers to organizations like the Sierra Club? Environmentalist and conservationist organizations traditionally have been concerned with ecological, not humanitarian issues. They make no pretense of acting for the sake of individual animals; rather, they attempt to maintain the diversity, integrity, beauty and authenticity of the natural environment. These goals are ecological, not eleemosynary. Their goals are entirely consistent, then, with licensing hunters to shoot animals whose populations exceed the carrying capacity of their habitats. Perhaps hunting is immoral; if so, environmentalism is consistent with an immoral practice, but it is

\footnotetext{
" Callicott, Animal Liberation: A Triangular Affair (1980), 2 Envt'l Ethics 311 at 315.

12 Leopold, supra note 1, at 269.

${ }^{13}$ Callicott, supra note 11 , at 314-15.
} 
environmentalism without quotes nonetheless. The policies environmentalists recommend are informed by the concepts of population biology, not the concepts of animal equality. The S.P.C.A. does not set the agenda for the Sierra Club.

I do not in any way mean to support the practice of hunting; nor am I advocating environmentalism at this time. I merely want to point out that groups like the Sierra Club, the Wilderness Society and the World Wildlife Fund do not fail in their mission insofar as they devote themselves to causes other than the happiness or welfare of individual creatures; that never was their mission. These organizations, which promote a love and respect for the functioning of natural ecosystems, differ ideologically from organizations that make the suffering of animals their primary concern - groups like the Fund for Animals, the Animal Protection Institute, Friends of Animals, the American Humane Association, and various single issue groups such as Friends of the Sea Otter, Beaver Defenders, Friends of the Earthworm, and Worldwide Fair Play for Frogs. ${ }^{14}$

D. G. Ritchie, writing in 1916, posed a difficulty for those who argue that animals have rights or that we have obligations to them created simply by their capacity to suffer. If the suffering of animals creates a human obligation to mitigate it, is there not as much an obligation to prevent a cat from killing a mouse as to prevent a hunter from killing a deer? "Are we not to vindicate the rights of the persecuted prey of the stronger?" Ritchie asks. "Or is our declaration of the rights of every creeping thing to remain a mere hypocritical formula to gratify pug-loving sentimentalists?"15

If the animal liberation or animal equality movement is not to deteriorate into "a hypocritical formula to gratify pug-loving sentimentalists," it must insist, as Singer does, that moral obligations to animals are justified, in the first place, by their distress, and, in the second place, by human ability to relieve that distress. The liberationist must morally require society to relieve animal suffering wherever it can and at a lesser cost to itself, whether in the chicken coop or in the wild. Otherwise, the animal liberationist thesis becomes interchangeable with the platitude one learns along with how to tie shoestrings: people ought not to be cruel to animals. I do not deny that human beings are cruel to animals, that they ought not to be, that this cruelty should be stopped and that sermons to this effect are entirely appropriate and necessary. I

\footnotetext{
14 Singer, supra note 8, at 201.

15 Ritchie, Natural Rights (3rd. ed., 1916) at 107. For an excellent discussion of this passage, see Clark, The Rights of Wild Things (1979), 22 Inquiry 171.
} 
deny only that these sermons have anything to do with environmentalism or provide a basis for an environmental ethic.

III.

In discussing the rights of human beings, Henry Shue describes two that are basic in the sense that "the enjoyment of them is essential to the enjoyment of all other rights."16 These are the right to physical security and the right to minimum subsistence. These are positive, not merely negative rights. In other words, these rights require governments to provide security and subsistence, not merely to refrain from invading security and denying subsistence. These basic rights require society, where possible, to rescue individuals from starvation; this is more than the merely negative obligation not to cause starvation. No; if people have basic rights - and I have no doubt they do - then society has a positive obligation to satisfy those rights. It is not enough for society simply to refrain from violating them.

This, surely, is true of the basic rights of animals as well, if we are to give the conception of "right" the same meaning for both people and animals. For example, to allow animals to be killed for food or to permit them to die of disease or starvation when it is within human power to prevent it, does not seem to balance fairly the interests of animals with those of human beings. To speak of the rights of animals, of treating them as equals, of liberating them, and at the same time to let nearly all of them perish unnecessarily in the most brutal and horrible ways is not to display humanity but hypocrisy in the extreme.

Where should society concentrate its efforts to provide for the basic welfare - the security and subsistence - of animals? Plainly, where animals most lack this security, when their basic rights, needs, or interests are most thwarted and where their suffering is most intense. Alas, this is in nature. Ever since Darwin, we have been aware that few organisms survive to reach sexual maturity; most are quickly annihilated in the struggle for existence. Consider as a rough but reasonable statement of the facts the following:

All species reproduce in excess, way past the carrying capacity of their niche. In her lifetime a lioness might have 20 cubs; a pigeon, 150 chicks; a mouse, 1,000 kits; a trout, 20,000 fry, a tuna or cod, a million fry or more; an elm tree, several million seeds; and an oyster, perhaps a hundred million spat. If one assumes that the population of each of these species is, from generation to generation, roughly equal, then on the average only one offspring will survive to replace each parent.

\footnotetext{
${ }^{16}$ Shue, supra note 10 , at $18-29$.
} 
All the other thousands and millions will die, one way or another. ${ }^{17}$

The ways in which creatures in nature die are typically violent: predation, starvation, disease, parasitism, cold. The dying animal in the wild does not understand the vast ocean of misery into which it and billions of other animals are born only to drown. If the wild animal understood the conditions into which it is born, what would it think? It might reasonably prefer to be raised on a farm, where the chances of survival for a year or more would be good, and to escape from the wild, where they are negligible. Either way, the animal will be eaten: few die of old age. The path from birth to slaughter, however, is often longer and less painful in the barnyard than in the woods. Comparisons, sad as they are, must be made to recognize where a great opportunity lies to prevent or mitigate suffering. The misery of animals in nature which humans can do much to relieve - makes every other form of suffering pale in comparison. Mother Nature is so cruel to her children she makes Frank Perdue look like a saint.

What is the practical course society should take once it climbs the spiral of moral evolution high enough to recognize its obligation to value the basic rights of animals equally with that of human beings? I do not know how animal liberationists, such as Singer, propose to relieve animal suffering in nature (where most of it occurs), but there are many ways to do so at little cost. Singer has suggested, with respect to pest control, that animals might be fed contraceptive chemicals rather than poisons. ${ }^{18}$ It may not be beyond the reach of science to attempt a broad program of contraceptive care for animals in nature so that fewer will fall victim to an early and horrible death. The government is spending hundreds of millions of dollars to store millions of tons of grain. Why not lay out this food, laced with contraceptives, for wild creatures to feed upon? Farms which so overproduce for human needs might then satisfy the needs of animals. The day may come when entitlement programs which now extend only to human beings are offered to animals as well.

One may modestly propose the conversion of national wilderness areas, especially national parks, into farms in order to replace violent wild areas with more humane and managed environments. Starving deer in the woods might be adopted as pets. They might be fed in kennels; animals that once wandered the wilds in misery might get fat in feedlots instead. Birds that now kill earthworms may repair instead to

\footnotetext{
${ }^{17}$ Hapgood, Why Males Exist (1979) at 34.

${ }^{18}$ Singer, supra note 8, at 198.
} 
birdhouses stocked with food, including textured soybean protein that looks and smells like worms. And to protect the brutes from cold, their dens could be heated, or shelters provided for the all too many who will otherwise freeze. The list of obligations is long, but for that reason it is more, not less, compelling. The welfare of all animals is in human hands. Society must attend not solely to the needs of domestic animals, for they are in a privileged class, but to the needs of all animals, especially those which, without help, would die miserably in the wild.

Now, whether you believe that this harangue is a reductio of Singer's position, and thus that it agrees in principle with Ritchie, or whether you think it should be taken seriously as an ideal is of no concern to me. I merely wish to point out that an environmentalist must take what $I$ have said as a reductio, whereas an animal liberationist must regard it as stating a serious position, at least if the liberationist shares Singer's commitment to utilitarianism. Environmentalists cannot be animal liberationists. Animal liberationists cannot be environmentalists. The environmentalist would sacrifice the lives of individual creatures to preserve the authenticity, integrity and complexity of ecological systems. The liberationist - if the reduction of animal misery is taken seriously as a goal - must be willing, in principle, to sacrifice the authenticity, integrity and complexity of ecosystems to protect the rights, or guard the lives, of animals.

IV.

A defender of the rights of animals may answer that my argument applies only to someone like Singer who is strongly committed to a utilitarian ethic. Those who emphasize the rights of animals, however, need not argue that society should enter the interests of animals equitably into the felicific calculus on which policy is based. For example, Laurence Tribe appeals to the rights of animals not to broaden the class of wants to be included in a Benthamite calculus but to "move beyond wants" and thus to affirm duties "ultimately independent of a desire-satisfying conception." 19 Tribe writes:

To speak of "rights" rather than "wants", after all, is to acknowledge the possibility that want-maximizing or utility-maximizing actions will be ruled out in particular cases as inconsistent with a structure of agreed-upon obligations. It is Kant, no Bentham, whose thought suggests the first step toward making us "different persons from the manipulators and subjugators we are in danger of becoming." 20

10 Tribe, From Environmental Foundations to Constitutional Structures: Learning From Nature's Future (1974), 84 Yale L. J. 545 at 551, 552.

$20 \mathrm{Id}$. at 552 . 
It is difficult to see how an appeal to rights helps society to "move beyond wants" or to affirm duties "ultimately independent of a desiresatisfying conception." Most writers in the Kantian tradition analyze rights as claims to something in which the claimant has an interest. ${ }^{21}$ Thus, rights-theorists oppose utilitarianism not to go beyond wants but because they believe that some wants or interests are moral "trumps" over other wants and interests. ${ }^{22}$ To say innocent people have a right not to be hanged for crimes they have not committed, even when hanging them would serve the general welfare, is to say that the interest of innocent people not to be hanged should outweigh the general interest in detering crime. To take rights seriously, then, is simply to take some interests, or the general interest, more seriously than other interests for moral reasons. The appeal to rights simply is a variation on utilitarianism, in that it accepts the general framework of interests, but presupposes that there are certain interests that should not be traded off against others. ${ }^{23}$

A second problem with Tribe's reply is more damaging than the first. Only individuals may have rights, but environmentalists think in terms of protecting collections, systems and communities. Consider Aldo Leopold's oft-quoted remark: "A thing is right when it tends to preserve the integrity, stability, and beauty of the biotic community. It is wrong when it tends to do otherwise."24 The obligation to preserve the "integrity, stability, and beauty of the biotic community," whatever those words mean, implies no duties whatever to individual animals in the community, except in the rare instance in which an individual is important to functioning of that community. For the most part, individual animals are completely expendable. An environmentalist is concerned only with maintaining a population. Accordingly, the moral obligation Leopold describes cannot be grounded in or derived from the

21 For discussion, see Feinberg, Duties, Rights, and Claims (1966), 3 Amer. Phil. Q. 137.

${ }^{22}$ See Dworkin, "Liberalism," in Hamphsire, ed., Public and Private Morality (1978) at 113-43. Rights "function as trump cards held by individuals." Id. at 136.

23 Barry observes:

On the surface, rights theories stand in opposition to utilitarianism, for rights, whatever their foundation (or lack thereof), are supposed to trump claims that might be made on behalf of the general welfare. The point here is, however, that the whole notion of rights is simply a variation on utilitarianism in that it accepts the definition of the ethical problem as conterminous with the problem of conflicting interests, and replaces the felicific calculus (in which the interests are simply added) with one which does not permit certain interests to be traded off against others.

Barry, "Self-government Revisited," in Miller and Siedentop, eds., The Nature of Political Theory (1983) at 125; see generally 121-54.

24 Leopold, supra note 1 , at 262. 
rights of individuals. Therefore, it has no basis in rights at all..$^{25}$

Consider another example: the protection of endangered species. ${ }^{20}$ An individual whale may be said to have rights, but the species cannot; a whale does not suddenly have rights when its kind becomes endangered. ${ }^{27} \mathrm{No}$; the moral obligation to preserve species is not an obligation to individual creatures. It cannot, then, be an obligation that rests on rights. This is not to say that there is no moral obligation with regard to endangered species, animals or the environment. It is only to say that moral obligations to nature cannot be enlightened or explained - one cannot even take the first step - by appealing to the rights of animals and other natural things.

\section{V.}

Garrett Hardin, in his "Foreword" to Should Trees Have Standing?, suggests that Stone's essay answers Leopold's call for a "new ethic to protect land and other natural amenities . . "28 But as one reviewer has pointed out,

Stone himself never refers to Leopold, and with good reason: he comes from a different place, and his proposal to grant rights to natural objects has emerged not from an ecological sensibility but as an extension of the philosophy of the humane movement. ${ }^{28}$

A humanitarian ethic - an appreciation not of nature, but of the wel-

${ }^{25}$ For discussion of this point, see Katz, Is There A Place For Animals in the Moral Consideration of Nature (1983), 4 Ethics and Animals 74; Norton, Environmental Ethics and Nonhuman Rights (1982), 4 Envt'l Ethics 17; Rodman, The Liberation of Nature? (1977), 20 Inquiry 83; Goodpaster, On Being Morally Considerable (1978), 75 J. Phil. 308.

Tom Regan discusses this issue in The Case for Animal Libertation (1983):

Because paradigmatic rights-holders are individuals, and because the dominant thrust of contemporary environmental efforts (e.g., wilderness preservation) is to focus on the whole rather than on the part (i.e., the individual), there is an understandable reluctance on the part of environmentalists to "take rights seriously," or at least a reluctance to take them as seriously as the rights view contends we should. . . . A rights-based environmental cthic ... ought not to be dismissed out of hand by environmentalists as being in principlc antagonistic to the goals for which they work. It isn't. Were we to show proper respect for the rights of individuals who make up the biotic community, would not the community be preserved?

(Id. at 362.) I believe this is an empirical question, the answer to which is "no". The environmentalist is concerned about preserving evolutionary processes; whether these processes, e.g., natural selection, have deep enough respect for the rights of individuals to be preserved on those grounds, is a question that might best left be addressed by an evolutionary biologist.

${ }^{28}$ The Endangered Species Act of 1973, 16 U.S.C. $\$ 1531$ (1976 \& Supp. I 1977 \& Supp. II 1978 \& Supp. III 1979).

${ }^{27}$ Feinberg, "The Rights of Animals and Unborn Generations," in Blackstone, cd., Philosophy and the Environmental Crisis (1974) 43 at 55-56.

${ }^{28}$ Hardin, "Foreward," in Stone, supra note 3, at xii.

${ }^{20}$ Rodman, supra note 25 , at 110 . 
fare of animals - will not help us to understand or to justify an environmental ethic. It will not provide necessary or valid foundations for environmental law. 
